\title{
PERAN KO KURIKULER DAN EKSTRAKURIKULER TERHADAP UPAYA PENCAPAIAN KURIKULUM 2013
}

\author{
Lutviyana Nur $\mathbf{H}$ \\ lutviyana1997@gmail.com \\ UIN Sunan Kalijaga Yogyakarta
}

\begin{abstract}
This article aims to describe the role and concepts of co-curricular and extracurricular activities so that it is useful for achieving the goals of the 2013 curriculum. This 2013 curriculum has three important objectives, namely Strengthening Character Education, Strengthening Literacy Culture, and 21st Century Learning. This type of research is library research, research sources are found in the literature and sources, or the latest findings regarding the Curricular and Extracurricular activities as well as the 2013 Curriculum. The results of this research are that co-curricular and extracurricular activities play a major role in achieving the three aspects of learning contained in the curriculum 2013, namely cognitive, affective and psychomotor aspects. These three aspects are very helpful in achieving the 2013 curriculum agenda, which consists of character strengthening, literacy culture and 21st century learning. Character strengthening can be achieved through religious extracurricular activities, Hisbul Wathan and BTQ, Kultum, work assignments, and intensive post-school guidance. Literacy culture can be achieved by reading guidance programs both reading the Al-Qur'an or spelling, one verse a day program. 21st century learning is pursued by extracurricular activities, namely tambourine activities, calligraphy and so on. The expected positive impact of this article is the dissemination of information about the urgency of co-curricular and extracurricular activities in an educational institution to achieve learning objectives in the 2013 curriculum.
\end{abstract}

Keywords: Co-curricular, Extracurricular, 2013 Curriculum

\begin{abstract}
Abstrak
Artikel ini bertujun untuk mendeskripsikan peran serta konsep dari kegiatan Ko kurikuler dan ekstrakurikuler sehingga bermanfaat untuk mencapai tujuan kurikulum 2013. Kurikulum 2013 ini memiliki tiga tujuan penting yaitu Penguatan Pendidikan karakter, Penguatan Budaya Literasi, dan Pembelajaran Abad 21. Jenis penelitian ini ialah penelitian kepustakaan (library research), sumber penelitan didapatkan
\end{abstract}


dalam literatur-literatur dan sumber-sumber, atau penemuan terbaru mengenai kegiatan Ko kurikuler dan Ekstrakurikule serta Kurikulum 2013. Hasil dari penelitiam ini adalah kegiatan Ko kurikuler dan ekstrakurikuler sangat berperan dalam pencapaian tiga aspek pembelajaran yang terdapat dalam kurikulum 2013 yaitu aspek kognitif, afektif dan juga psikomotorik. Ke tiga aspek tersebut selanjtnya sangat membantu dalam pencapaian agenda kurikulum 2013 yang terdiri dari penguatan karakter, budaya literasi dan pembelajaran abad 21. Penguatan karakter bisa ditempuh dengan ekstrakirikuler keagamaan, Hisbul Wathan dan BTQ, Kultum, tugas prakarya, dan juga bimbingan intensif sepulang sekolah. Budaya Literasi bisa dicapai dengan program bimbingan membaca baik membaca Al-Qur'an atapun mengeja, program sehari satu ayat. Pembelajaran abad 21, ditempuh dengan kegiatan ekstrakurikuler yaitu kegiatan rebana, kaligrafi dan sebagainya. Dampak positif yang diharapkan dengan adanya artikel ini ialah tersebarnya informasi mengenai urgennya kegiatan Ko kurikuler dan Ekstrakurikuler pada sebuah Lembaga Pendidikan untuk mencapai tujuan pembelajaran pada kurikulum 2013.

\section{Kata Kunci: Ko kurikuler, Ekstrakurikuler, Kurikulum 2013}

\section{A. Pendahuluan}

Tujuan pendidikan nasional tidak hanya menekankan pada aspek intelektual namun juga lebih luas dari itu yakni mencakup moral, sosial, dan karakter peserta didik atau dengan kata lain menciptakan manusia Indonesia seutuhnya. Berkaitan dengan tersebut, dalam aspek pendidikan, unsur yang teramat penting untuk dibahas adalah kurikulum. Tanpa adanya kurikulum, sulit rasanya bagi para perencana pendidikan untuk mencapai tujuan pendidikan yang diselenggarakannya. Mengingat pentingnya kurikulum, maka ia perlu dipahami dengan baik oleh semua pelaksana pendidikan. Kurikulum merupakan sesuatu yang harus ditempuh jika dalam dunia pendidikan berarti sesuatu yang harus ditempuh untuk mencapai tujuan tertentu yang disajikan dalam mata pelajaran dalam lembaga pendidikan. ${ }^{1}$

Kurikulum pendidikan selalu mengalami perkembangan. Kurikulum selalu mengalami revolusi mengikuti perkembangan zaman yang terjadi di dalam

${ }^{1}$ S. Nasution. Asas-Asas Kurikulum. (Bandung: Jemmars, 1982), Ed. 6. Hlm. 7-8 
masyarakat. Akan tetapi perubahan dan perkembangan kurikulum tidak selalu diartikan secara total, tetapi sifatnya lebih merupakan revisi. ${ }^{2}$ Kurikulum yang sedang di terapkan saat ini di satuan pendidikan di Indonesia adalah kurikulum 2013. Direktur Jenderal Pendidikan Dasar dan Menengah Kemdikbud, Hamid Muhammad pada saat menyampaikan sambutan pada kegiatan Bimbingan Teknis (Bimtek) Tim Pengembang Kurikulum 2013 Sekolah Dasar Tingkat Provinsi tanggal 14 Maret 2017 mengatakan bahwa ada 3 (tiga) hal penting yang menjadi agenda K-13, yaitu; penguatan pendidikan karakter, penguatan literasi, dan pembelajaran abad 21. ${ }^{3}$ Untuk memnuhi ketiga hal tersebut diperlukan rancangan kurikulum yang menyukseskan ke tiga agenda dalam kurikulum 2013.

Salah satu agenda penting di dalam pelaksaaan kurikulum adalah kegiatan kurikuler. Di mana kurikuler tersebut terdapat tiga kegiatan yaitu kegiatan Intrakurikuler, Kokurikuler dan Ekstrakurikuler. Ketiga kurikulum tersebut sangat penting untuk di bahas mengingat kegiatan tersebut merupakan bagian dari kurikulum pendidikan yang sangat menunjang tercapainya tujuan pembelajaran terutama untuk menjalankan isi dan amanah dari kurikulum 2013. Dalam makalah ini, penulis akan fokus terhadap KO dan Ekstrakurikuler di mana kegiatan ini merupakan kegiatan di luar jam pelajaran yang sangat membantu dalam pemenuhan kegiatan pada kurikulum 2013. Kedua kegaiatan tersebut merupakan merupakan proses menyempurnakan pendidikan pada tingkat kognitif menuju berkesinambungan ke aspek afektif dan psikomotorik yang berguna untuk menjembatasi berbagai permasalahan pendidikan di Indonesia terutama masalah mutu pendidikan.. ${ }^{4}$ dengan hal ini, ekstrakurikuler termasuk Ko Kurikuler adalah jembatan saat proses evaluasi pembelajaran di mana biasanya pada proses evaluasi, hanya aspek kognitif yang diperdebatkan, namun aspek afektif dan

2 Abdullah Idi. Pengembangan Kurikulum: Teori dan Praktik. (Jakarta: Gaya Media Pratama, 1999). Cet 1.Hlm. 218

3 Idris Apandi. Tiga Agenda Penting Implementasi Kurikulum 2013.

Di akses dari

https://www.kompasiana.com/idrisapandi/58c84e225597733c447dcc57/tiga-agenda-penting-imple mentasi- kurikulum-2013?page=all. Pada Tanggal 28 Maret 2020 Pukul 11.5

4 Muh. Hambali, Eva Yulianti. Jurnal, Ekstrakurikuler Keagamaan terhadap Pembentukan Karakter Religius Peserta Didik di Kota Majapahit.Malang, UIN Maulana Malik Ibrahim Malang, vol 05. No.02, 2018. Hal. 196 
psikomotoriknya di nomor duakan.

Dengan keseimbangan aspek kognitif, afektif dan juga psikomotorik, untuk mencapai tujuan kurikulum 2013 yang telah disampaiakn tadi menjadi lebih mudah. penguasaan aspek kognitif bisa membantu siswa dalam penguatan budaya literasi, begitupun dengan aspek afektif dan psikomotorik bisa membantu siswa dalam penguatan karakter serta keterampilan lain yang diperlukan untuk menunjang pembelajaran abad 21 yaitu tuntutan pembelajaran yang inovatif dan kreatif. Untuk itu, perlu dibahas secara lebih dalam tentang konsep KO kurikuler dan Ekstrakurikuler sebagai upaya untuk mrncapai tujuan dari kurikulum 2013.

\section{B. Pembahasan}

\section{1) Kajian Teori}

\section{Agenda Pokok Kurikulum 2013}

Sesuai dengan penjelasan dalam permasalahan di dalam pendahuluan di atas, bahwa kurikulum 2013 mempunyai agenda penting yatu penguatan karakter, penguatan budaya literasi dan juga pembelajaran abad 21. Program penguatan karakter menjadi perhatian Presiden mengignat perbaikan karater pada generasi sekarang akan mempengaruhi generasi 30 tahun yang akan datang. Dengan karakter yang bagus, maka kepemimpinan yang akan mendatang dipastikan menjadi kepemimpinan dengan karakter yang baik dan juga kuat serta menjadi jembatan antara sekolah dengan ruang komunitas untuk pengembangan nilai-nilai luhur. ${ }^{4}$ Ada beberapa cara yang bisa dilakukan dalam upaya penguatan karakter siswa diataranya adalah program 5 S yaitu “Senyum, Salam, Sapa, Sopan, dan Santun”.

Agenda selanjutnya adalah penguatan buadaya literasi. Budaya literasi merupakan bentuk pengembangan terhadap asumsi dan kebutuhan perkembangan zaman. ${ }^{5}$ Tuntutan zaman yang semakin banyak menjadi faktor penyebab manusia harus dibekali banyak kemampuan. Literasi yang

5 Asri Harfiyani,. Jurnal. Penguatan Pendidikan Karakter Melalui Budaya Literasi Dalam Konteks Pembelajaran Abad 21 Di Sekolah Dasar. Prosiding Seminar dan Diskusi Nasional Pendidikan Dasar Program Pascasarjana, Universitas Negeri Jakarta. 2018 Hal. 142 
merupakan salah satu bekal bagi siswa untuk mengembangkan kemampuan sekaligus untuk menjawab tantangan di masa sekarang dan yang akan datang. Penguatan budaya literasi bisa di terapkan melalui kegiatan perencanaan, pembiasaan pengembangan, pembelajaran dan evaluasi. Contoh penerapan dari kegiatan tersebut dijelaskan dalam penelitian dari Aisyah Rahmawati. Dalam penelitiananya di di SD Muhammadiyah Program Khusus Kota Barat Surakarta. ${ }^{6}$ Pada tahap perencanaan harus disesuaiakan dengan aturan pemerintah dan juga dan juga indikator yang dikembangkan dengan bermacam-macam kegiatan literasi seperti Literasi pagi (Morning Spirit), pojok baca, mading kelas, literasi perpustakaan, outing class, lomba literasi, ekstrakurikuler jurnalistik, media publikasi, bulan bahasa, membaca bersama surat kabar, perpustakaan keliling.

Selanjutnya kegiatan pembiasaan. Kegiatan pembiasaan bisa dilakukan saat 15 menit sebelum pelajaran dimulai. Siswa diminta membaca buku yang telah disediakan dilengkapi dengan berbagai poster kampanye membaca di kelas, koridor, dan area lain di sekolah, disediakan pula bahan kaya teks di setiap kelas, semua pihak terlibat dalam rangka mensukseskan pelaksanaan penguatan karakter melalui GLS. Sekolah juga dilengkapi dengan berbagai fasilitas penunjang GLS seperti perpustakaan, lorong baca dan pojok baca yang berisi buku baik pelajaran maupun non pelajaran dan lain-lain yang sesuai tuntutan pada tahap pembiasaan.

Pada tahap pengembangan sudah dilaksanakan sesuai pada buku panduan misalnya dilakukan di perpustakaan dan siswa harus menanggapi isi buku yang dibaca. Pada tahap pembelajaran artinya siswa sudah mebgaplikasikan literasi pada saat pembe;ajaran maupun di liar jam pelajaran. Evaluasi disesuaikan dengan indikator pencapaian tahapan dan semua program literasi dievaluasi. ${ }^{7}$

6 Aisyah Rahmawati, Skripsi. Penguatan Karakter Gemar Membaca Dan Rasa Ingin Tahu Siswa Melalui Gerakan Literasi Sekolah Di Sd Muhammadiyah Program Khusus Kottabarat Surakarta Tahun Ajaran 2018/2019. Pendidikan Guru Sekolah Dasar Fakultas Ilmu Keguruan Dan Pendidikan Universitas Muhammadiyah Surakarta 2019. Hal. 5-6

7 Gerakan Literasi Sekolah Di Sd Muhammadiyah Program Khusus Kottabarat 
Agenda yang ke tiga adalah Pembelajaran abad 21 . pembelajaran abad 21 adalah pembelajaran dimana para siswa sebagai obyek pembelajaran dituntut untuk menguasai tekhnologi yang digunakan untuk menyeimbangkan tuntutan zaman. Sejalan dengan pendapat tersebut Greenstein dalam tulisannya menyatakan bahwa siswa yang hidup pada abad 21 harus menguasai keilmuan, berketerampilan metakognitif, mampu berpikir kritis dan kreatif, serta bisa berkomunikasi atau berkolaborasi yang efektif, keadaan ini menggambarkan adanya kesenjangan antara harapan dan kenyataan. ${ }^{8}$ Oleh karena itu, pemerintah merancang pembelajaran abad 21 melalui kurikulum 2013 yang berbasis pada siswa. Guru sebagai kepanjangan tangan dari pemerintah di sekolah sekolah menerapkan pembelajaran abad 21. Di sekolah formal, pembelajaran sudah dituntut untuk menerapkan kemampuan 4C (Critical Thinking, Communiaction, Collaboration , Creativity).

\section{Desain Kegiatan Ko Kurikuler Dan Ekstrakurikuler}

Dalam pelaksanaan pendidikan di sekolah biasanya dikenal adanya tiga Program pokok, yaitu Program intrakurikuler, kokurikuler, dan ekstrakurikuler. Ketiga Program tersebut merupakan satu kesatuan yang utuh yang tidak dapat terpisahkan dalam upaya mencapai tujuan pendidikan dalam suatu sekolah. Kegiatan Ko kurikuler dan Ekstrakurikuler merupakan kegiatan untuk menunjang pencapaian aspek afektif dan psikomotik. Oleh karenanya, Ko kurikuler dan ekstrakurikuler adalah jembatan saat proses evaluasi pembelajaran di mana biasanya pada proses evaluasi, hanya aspek kognitif yang diperdebatkan, namun aspek afektif dan psikomotoriknya di nomor duakan.

\section{Kegiatan Ko Kurikuler}

Kokurikuler merupakan kegiatan di luar jam pelajaran biasa (termasuk waktu libur) yang dilakukan di sekolah ataupun di luar sekolah

Surakarta Tahun Ajaran 2018/2019. Pendidikan Guru Sekolah Dasar Fakultas Ilmu Keguruan Dan Pendidikan Universitas Muhammadiyah Surakarta 2019. Hal. 5-6

${ }^{8}$ Greenstein, L. Assessing 21st Century Skills:a guide to evaluating mastery and authentic learning. London: Sage Publications Ltd. 2012. 
dengan tujuan untuk memperluas pengetahuan siswa mengenai hubungan antara berbagai jenis pengetahuan, menyalurkan bakat dan minat, serta melengkapi upaya pembinaan manusia sutuhnya. ${ }^{9}$ Kegiatan Kokurikuler adalah kegiatan yang sangat erat sekali dan menunjang serta membantu kegiatan intrakurikuler biasanya dilaksanakan diluar jadwal intrakurikuler dengan maksud agar siswa lebih memahami dan memperdalam materi yang ada di intrakurikuler, biasanya kegiatan ini berupa penugasan atau pekerjaan rumah ataupun tindakan lainnya yang berhubungan dengan materi intrakurikuler yang harus diselesaikan oleh siswa.

Kegiatan ini dapat dilakukan secara individual maupun kelompok. Dalam hal ini, perlu diperhatikan ialah menghindari terjadinya pengulangan dan ketumpang-tindihan antara mata pelajaran yang satu dengan mata pelajaran lainnya. Selain itu, tugas yang diberikan tidak boleh melebihi kapasitas dari siswa. Jangan sampai siswa keberatan mengerjakan tugas dari beberapa guru pengampu. Tugas guru disini adalah melakukan koordinasi antar guru lainnya agar jadwal kegiatan kokurikuler bisa selaras dan sesuai dengan ketentuan.

Dalam melaksanakan kegiatan kokurikuler, adal hal-hal yang harus diperhatikan, diantaranya, tugas kokurikuler hendaknya jelas dan sesuai dengan pokok bahasan atau sub pokok bahasan yang sedang diajarkan, guru hendaknya tahu mengenai tingkat kesulitannya bagi siswa sehingga tugas yang diberikan kepada siswa itu sesuai dengan kemampuannya dan tidak memberatkan baik pada fisiknya maupun psikisnya, penilaian tugas kokurikuler, hendaknya jelas dan adil sesuai dengan hasil masing-masing kemampuan siswa dan guru juga hendaknya dengan tugas kokurikuler ini bisa membantu dalam penentuan nilai raport. Ko Kurikuler bertujuan sebagai kegiatan yang membantu pendalaman materi yang belum di pahami dalam kegiatan intrakurikuler. Selain itu, bagi guru, Ko kurikuler bertujuan sebagai penentuan nilai raport. Jenis kegiatannya bisa berupa kegiatan

9 Moh. Uzer Usman dan Lilis Setiawati, Upaya Optimalisasi Kegiatan Belajar Mengajar, (Bandung: Remaja Rosdakarya, 1993), hlm. 17. 
individu maupun kegiatan kelompok.

Kegiatan Ko kurikuler ternyata tidak hanya untuk pengembangan kemampuan siswa, namun juga bermanfaat untuk menunjang kemampuan guru salah satunya melalui program PPG. ${ }^{10}$ comtoh lain kegiatan ko kurikuler adalah kegiatan BTQ, Kultum, tugas prakarya, dan juga bimbingan intensif sepulang sekolah ataupun sebelum pelajaran di mulai. Sebagai contoh adalah kegiatan pembiasaan berhijab untuk perempuan di MTs Gunung Jati Jombang adalah dengan melakukan bimbingan intensif sepulan sekolah. Pengaplikasiannya atau untuk memotivasinya adalah dengan diadakan kegiatan seminar, talk show ataupun ceramah biasa. ${ }^{11}$

\section{Kegiatan Ekstrakurikuler}

Menurut Kamus Besar Bahasa Indonesia (KBBI) ekstrakurikuler yaitu”Suatu kegiatan yang berada di luar program yang tertulis di dalam kurikulum seperti latihan kepemimpinan dan pembinaan siswa”. Berdasarkan Peraturan Menteri Pendidikan Nasional Republik Indonesia Nomor 39 Tahun 2008 tentang Pembinaan Kesiswaan, Kegiatan ekstrakurikuler merupakan salah satu jalur pembinaan kesiswaan.

Kegiatan ekstrakurikuler itu sendiri dilaksanakan di luar jam pelajaran wajib. Kegiatan ekstrakurikuler ini lebih berfitas fleksibel untuk siswa, artinya bahwa siswa bebas menentukan jenis kegiatan ekstrakurikuler yang ada di sekolah sesuai dengan bakat dan minatnya masing-masing, Kegiatan ekstrakurikuler yang diikuti dan dilaksanakan oleh siswa baik di sekolah maupun di luar sekolah, bertujuan agar siswa dapat memperkaya dan memperluas diri.

Pelaksanaan kegiatan ekstrakurikuler ditangani langsung oleh guru atau pembimbing khusus dibidangnya masing-masing dan atas persetujuan serta

10 Hermanto SP, Jurnal. Penambahan Program Wajib Kokurikuler Sebagai Redesain Sistem Pendidikan Guru. PLB FIP UNY. Hal 4

11 Nurul Husni Hidayah, Skripsi. Peran Program Ko-Kurikuler untuk Memotivasi Siswa Menutup Aurat (Berhijab) dalam Keseharian (Studi Kasus di MTs. Gunung Jati Jombang).Jurusan Pendidikan Agama Islam GFakultas Ilmu Trabiyah dan Keguruan UIN Maulana Malik Ibrahim Malang. 2018. Hal. xvii 
tanggung jawab dari kepala sekolah. Kegiatan ekstrakurikuler di isi dengan berbagai macam bentuk kegiatan antara lain olahraga, keagamaan, kesenian dan lainnya sesuai dengan kemampuan bakat dan minat siswa di sekolah. Keseluruhan jenis kegiatan tersebut dimaksudkan untuk mrnambah krahlian dan wawasan siswa serta membangun kepribadian diri yang positif pada masing-masing peserta didik.

Kegiatan-kegiatan tersebut selanjutnya secara garis besar dibagi menjadi dua macam kegaiatan Ekstrakurikuler yaitu ekstrakurikuler wajib dan ekstrakurikuler pilihan. Ekstrakurikuler wajib merupakan program ekstrakurikuler yang harus diikuti oleh seluruh peserta didik, terkecuali bagi peserta didik dengan kondisi tertentu yang tidak memungkinkannya untuk mengikuti kegiatan ekstrakurikuler tersebut. Ekstrakurikuler pilihan merupakan program ekstrakurikuler yang dapat diikuti oleh peserta didik sesuai dengan bakat dan minatnya masing-masing. ${ }^{12}$

Dalam melaksanakan kegiatan ekstrakurikuler ini, ada hal-hal yang harus diperhatikan, supaya kegiatan ini berlangsung dengan baik, diantaranya yaitu bermanfaat bagi siswa baik buat masa kini maupun masa yang akan datang, tidakmembebani bagi siswa, bisa memanfaatkan lingkungan sekitar, alam, industri, dan dunia usaha serta tidak mengganggu kegiatan yang utama, yakni kegiatan intrakurikuler. Kegiatan ektrakurikuler sendiri bertujuan untuk mengembangkan prestasi, bakat, keterampilan, kepribadian dan kreativitas lainnya dalam rangka mencapai pendidikan yang sesungguhnya.

Beberapa manfaat dari kegiatan ekstrakurikuler adalah siswa terlatih dalam satu organisasi atau kegiatan EO (Even Organizer), terlatih menjadi seorang pemimpin, terlatih berinteraksi dengan kegiatan luar sekolah, terlatih mempunyai suatu keterampilan, sebagai benih untuk berkembang ke depan, terlatih menghargai kelebihan orang lain, terlatih menghadapi tantangan yang datang, terlatih membuat relasi yang langgeng (interpersonal, termotivasi

12 Peraturan Menteri Pendidikan Dan Kebudayaan Republik Indonesia Nomor 81A Tahun 2013 Tentang Implementasi Kurikulum 
akan cita-citanya/ karir yang akan ia raih, merasa bertanggungjawab atas kemajuan sekolahnya, menghargai jerih payah orang tuanya dan berwawasan internasional.

Kegiatan ekstrakurikuler dalam Peraturan Menteri Pendidikan Dan Kebudayaan Republik Indonesia Nomor 81A Tahun 2013 Tentang Implementasi Kurikulum mempunyai beberpa fungsi yaitu untuk mengembangkan kemampuan siswa, mengembangkan rasa tanggung jawab siswa, menciptakan suasana rileks pada siswa dan juga pengembangan kesiapan karir siswa di masa sekarang maupun yang akan datang. ${ }^{13}$

Kegiatan ekstrakurikuler dalam Peraturan Menteri Pendidikan Dan Kebudayaan Republik Indonesia Nomor 81A Tahun 2013 Tentang Implementasi Kurikulum mempunyai prinsip Individual, yaitu prinsip kegiatan ekstra kurikuler yang sesuai dengan potensi, bakat dan minat peserta didik masing-masing. Pilihan, yaitu prinsip kegiatan ekstra kurikuler yang sesuai dengan keinginan dan diikuti secara sukarela peserta didik. Keterlibatan aktif, yaitu prinsip kegiatan ekstra kurikuler yang menuntut keikutsertaan peserta didik secara penuh. Menyenangkan, yaitu prinsip kegiatan ekstra kurikuler dalam suasana yang disukai dan mengembirakan peserta didik. Etos kerja, yaitu prinsip kegiatan ekstra kurikuler yang membangun semangat peserta didik untuk bekerja dengan baik dan berhasil. Kemanfaatan sosial, yaitu prinsip kegiatan ekstra kurikuler yang dilaksanakan untuk kepentingan masyarakat. ${ }^{14}$

Adapun bentuk-bentuk kegiatan ekstrakurikuler adalah Krida; meliputi kepramukaan, latihan dasar kepemimpinan siswa (LDKS), palang merah remaja (PMR), pasukan pengibar bendera pusaka (paskibraka), dan lainnya, Karya ilmiah; meliputi kegiatan ilmiah remaja (KIR), kegiatan penguasaan keilmuan dan kemampauan akademik, penelitian, dan lainnya.

13 Peraturan Menteri Pendidikan Dan Kebudayaan Republik Indonesia Nomor 81A Tahun 2013 Tentang Implementasi Kurikulum

14 Ibid, 
Latihan/olah bakat/prestasi ; meliputi pengembangan bakat oleh raga, seni, dan budaya, cinta alam,jurnalistik, teater, keagamaan, dan lainnya. ${ }^{15}$

\section{2) Metode Penelitian}

Jenis penelitian ini termasuk dalam kategori penelitian kepustakaan (library research), yaitu, pertama, dengan mencatat semua temuan mengenai motivasi konsumsi secara umum pada setiap pembahasan penelitian yang didapatkan dalam literatur-literatur dan sumber-sumber, dan atau penemuan terbaru mengenai kegiatan $\mathrm{KO}$ dan Ekstrakurikuler dalam Implementasi kurikulum 2013. Dengan menggunakan data-data dari berbagai referensi baik primer maupun sekunder. Data-data tersebut dikumpulkan dengan teknik dokumentasi, yaitu dengan cara membaca (text reading), mempelajari, mengkaji literatur seperti buku, jural, karya ilmiah, dan penelitian-penelitian lain yang berkaitan dengan pembahasan yang dibahas dalam tulisan ini.

\section{3) Hasil Penelitian}

\section{Ko Korikuler Dan Ekstrakurikuler Dalam Kurikulum 2013}

Kurikulum 2013 merupakan kurikulum yang diterapkan pada tahun pembelajaran 2013/2014. Kurikulum ini adalah perbaikan atau pengembangan dari kurikulum yang sudah ada sebelumnya. di mana kurikulum 2013 ini mempunyai tiga agenda penting yaitu penguatan karakter, penguatan literasi dan pembelajaran abad 21.Untuk mencapai ke tiga agenda dalam kurikulum 2013 tersebut, dapat di capai salah satunya dengan program Ko kurikuler dan Ekatrakurikuler. Dimana kegiatan ini bersifat lebih fleksibel dan mempunyai kegiatan yang lebih banyak dibandingkan dengan pembelajaran di dalam kelas atau intrakurikuler.

Kegiatan Ko kurikuler tidak harus mengacu kepada kurikulum sekolah karena kegiatan tersebut dilakukan pada jam diluar jam pelajaran. Hal ini dijelaskan dalam penelitian dari Ferlina Khoirun Nisa tentang Program Ko kurikuler Sinematografi di SMK Negeri 11 Semarang. Dalam penelitiannya

15 Permendikbud no.18 A 2013 
meneyebutkan bahwa ko kurikuler Sinematografi yang dilaksanakan di SMK Negeri 11Semarang merupakan program sekolah yang dilaksanakan di luar jam pelajaran tidak tercantum dalam struktur kurikulum sekolah, selain itu program ini juga dapat dikategorikan sebagai kegiatan tambahan untuk meningkatkan kompetensi peserta didik sesuai dengan kebutuhan kompetensi yang perlu di dalami pada jurusan Multimedia. ${ }^{16}$

Kegiatan Ko kurikuler harus mempunyai desain yang jelas agar tujuan dari kurikulum yang ada di sekolah bisa dicapai dengan baik. Untuk membuat desain pengembangan ko kurikuler pada kurikulum 2013 membutuhkan langkah-langkah yang baik. Departemen Pedidikan dan Kebudayaan merumuskan langkah-langkah pelaksanaan kokurikuler adalah dengan menetukan penugasan kepada siswa, pencatatan tugas, pelaksanaan tugas dan selanjutnya adalah penilaian tugas. ${ }^{17}$ kegiatan tesebut dilakukan oleh guru pembimbing khususnya dan juga pihak sekolah dalam merancang kegiatan Kokurikuler.

Kegiatan ko kurikuler jelas sangat membantu pencapaian kurikulum 2013. Dari jenis kegiatan yang dilakukan, diantaranya adalah kegiatan dengan contoh BTA, Praktek mapel, dan penugasan tugas prakarya atau kesenian lain seperti tilawah, membaca buku sebelum jam pelajaran dan juga bimbingan tambahan setelah pulang sekolah menjadi contoh kegiatan yang mampu mencapai agenda kurikulum 2013. Dengan kegiatan yang telah di contohkan, siswa dengan mudah menguatkan budaya liteasi, pendidikan karakter dan juga inovativ serta kreatif seperti desain pembelajaran abad 21.

Hasil penelitian membutukan bahwa kegiatan ko kurikuler mampu meningkatkan karakter siswa. Penelitian yang dilakukan oleh Abdul Malik Kusuma Negara menyebutkan bahwa dengan kegiatan ko kurikuler PAI, siswa

16 Ferlina Khoirun Nisa, Skripsi. Evaluasi Program Ko-Kurikuler Sinematografi”'Two Weeks One Video" pada Siswa Kelas X Prodi Multimedia di SMK Negeri 11 Semarang”, ( Semarang: Kurikulum Teknologi Pendidikan Fakultas Ilmu Pendidikan Universitas Negeri Semarang. 2018.) Hlm. 83

17 Departemen Pendidikan dan Kebudayaan Direktorat Jendral Pendidikan Dasar dan Menengah Direktorat Pendidikan Menengah Umum 1984 Petunjuk Pelaksanaan dan Pengelolaan Kurikulum 1984 Sekolah Menengah Umum Tingkat Atas (SMA) jakarta.hlm 33-34 
menjadi berjiwa karakter religious dan semakin giat menjalankan ajaran agamanya. Kegiatan ko kurikuler yang dilakukan di MA Muhammadiyah Baturetno (Wonogiri) adalah Baca tulis dan tadarus Al-Qur'an (BTA), Kultum ba'da dhuhur, Praktik PAI, Peringatan hari-hari besar Islam (PHBI), Pesantren kilat,. Kunjungan studi (Rihlah) yang dilakukan 1 atau 2 tahun sekali, Lomba-lomba keagamaan, dan Tugas rumah, yang diberikan hampir setiap minggu. ${ }^{18}$

Kegiatan ini harus dirancang secara matang. dalam perencanaan kegiatan ekstrakurikuler akan dibahas meliputi jenis-jenis kegiatan ektrakurikuler, bentuk dan tujuan kegiatan, pembagian tugas pembina ekstrakurikuler, pembentukan pengurus, pengawas, ekstrakurikuler, menyusun program kerja dan jadwal kegiatan, anggaran, mekanisme monitoring dan evaluasi, serta sarana prasarana yang dibutuhkan. ${ }^{19}$

Selanjutnya harus dilaksanakan pengorganiasian dalam ekstrakurikuler. Perlunya dilakukan pembagian dan pendelegasian tugas, tanggung jawab, wewenang kepala sekolah, wakil kepala sekolah bidang pengembangan diri, pembina kegiatan, pengurus, dan pelatih ke gitan ekstrakurikuler. Pembagian tugas dan pembentukan struktur organisasi kegiatan ekstrakurikuler ditetapkan oleh kepala sekolah melalui surat keputusan. Dengan pembagian ini, diharapkan perencanaan yang sudah disusun akan mengakibatkan dampak yang baik bagi sekolah khususnya siswa. Peran kegiatan ekstrakurikuler bagi guru adalah guru bertindak sebagai Pembina yang melaksanakan sistem dengan terbuka yaitu tidak memaksakan juga sebagai pengendali kegiatan ekstrakurikuler terserbut dan sekaligus penentu keberhasilan siswa dalam kegiatan ekstrakurikuler.

Sebagai contoh adalah kegiatan Kegiatan ekstrakurikuler keagamaan yang mempunyai peran terhadap mutu pembelajaran PAI di sekolah dengan

18 Abdul Malik Kusuma Negara, Skripsi. Pembinaan Karakter Keislaman Siswa Melalui Ko-Kurikuler Pai Di Ma Muhammadiyah Baturetno, Wonogiri. Pendidikan Agama Islam Fakultas Ilmu Tarbiyah Dan Keguruan Universitas Islam Negeri Sunan Kalijaga Yogyakarta, 2017. Hal. 81-82

19 Romadon Taufik, Jurnal. Manajemen Kegiatan Ekstrakurikuler Berbasis Karakter Siswa. Manajer Pendidikan, Volume 9, Nomor 4, 2015. Hal. 497 
konsep utama yaitu membawa siswa lebih inovatif dan kritis. Berbagai macam kegiatan ekstrakurikuler keagamaan seperti program baca tulis al-qur'an, seni kaligrafi, tilawah, karya tulis ilmiah, pentas seni, pesantren kilat, dan berbagai macam kegiatan lainnya sangat bermanfaat untuk menunjang kehidupan siswa kedepannya.

Penelitian dari Muh. Hambali dan Eva Yulianti menyebuatkan bahwa pelaksanaan ekstrakurikuler keagamaan dalam pembentukan karakter religius peserta didik di SMP Islam Brawijaya Kota Mojokerto mempunyai implikasi yang kuat akan adanya nilai-nilai Islami baik nilai Ilahiyah maupun Insaniyah yang mencerminkan nilai-nilai karakter religius yang terbentuk dari keaktifan dan semangat belajar yang tinggi peserta didik dalam mengikuti pelaksanaan ekstrakurikuler keagamaan di sekolah dengan tekun dan tanggungjawab. ${ }^{20}$

Penelitian lain yang dilakukan oleh Budi Santoso menyebutkan bahwa kegiatan ekstrakurikuler keagamaan dapat berdampak positif pada penguatan karakter siswa yaitu melalui kegiatan ekstrakurikuler "Hisbul Wathon”. Budi Santoso menuliskan dalam hasil penelitiannya bahwa kegiatan eksrtakurikuler di SMK Muhammadiyah Aimas adalah kegiatan Ekstrakurikuler Hisbul Wathan sebagai praktik moral dari kegiatan belajar-mengajar di kelas. Pengembangan kegiatan ekstrakurikuler yang mengimplementasikan antara pengetahuan yang diperoleh di kelas dengan sikap dan keterampilan yang mesti dikembangkan agar dapat dimiliki siswa berupa nilai-nilai budi pekerti luhur yang telah menjadi budaya dalam kehidupan sosial. ${ }^{21}$

Untuk rogram penguatan budaya literasi, ekstrakurikuler juga berperan penting di dalamnya. Berbagai macam kegiatan ekstrakurikuler yang dilaksanakan di sekolah sangat membantu meningkatkan kegiatan budaya literasi. Pasalnya setiap kegiatan ekstrakurikuler, sisiwa dituntut untuk lebih banyak membaca situasi baik berita, buku, atapun sumber lain untuk meng update program-program yang sesuai dengan kondisi zaman. Seperti kegiatan

20 Muh. Hambali, Eva Yulianti. Jurnal. Ekstrakurikuler Keagamaan terhadap Pembentukan Karakter Religius Peserta Didik di Kota Majapahit.(Malang, UIN Maulana Malik Ibrahim Malang, vol 05. No.02, 2018), hal.206

21 Budi Santoso, Jurnal. Penguatan Pendidikan Karakter melalui Kegiatan 
ekstrakurikuler "literasi digital keagamaan” yang dilaksanakan di MAN kota Bandung. Kegiatan literasi digital keagamaan ini sudah pada tahap menemukan, menggunakan, dan menyebarluaskan informasi keagamaan yang dapat diakses melalui website yang dikunjungi untuk keperluan berdakwah.Kegiatan yang dilaksanakan sangat berperan untuk kelangsungan pembelajaran PAI baik pembelajaran yang dilaksanakan di kelas maupun di luar kelas. ${ }^{22}$

Dalam pengembangan jiwa kreativitas siswa, ekstrakurikuler dan ko kurikuler mempunyai peran sangat besar. Dalam kegiatannya yang bersifat lebih ringan daripada intrakurikuler memberikan keleluasaan siswa dan guru pengampu maupun pihak sekolah untuk mengasah lebih dalam kreativitas siswa. Penelitian membuktikan bahwa kreativitas siswa bisa di asah melalui kegiatan ekstrakurikuler. Penelitian dari Suciati Nur Apriyanti dan Syarip Hidayat membuktikan bahwa program ekstrakurikuler teater bisa menumbuhkan jiwa kreativitas siswa. ${ }^{23}$ Penelitian lain Irawati A. Sahman menyebutkan bahwa ekstrakurikuler seni kaligrafi mampu meningkatkan kreatifitas siswa. Kegiatan tersebut merupakan kegiatan yang dilaksanakan di Madrasah Aliyah Muhammadiyah Nunu Palu. ${ }^{24}$

Dari beberapa penelitian tersebut, dapat dibuktikan bahwa kegiatan ekstrakurikuler memberikan peran penting terhadap penguatan nilai-nikai keagamaan yang dicontohkan dalam penguatan karakter, dan penumbuhan jiwa kepemimpinan yang dilakukan melalui rohis. Selain itu dalam aspek kognitif, silaksanakan melalui kegiatan ekstrakurikuler literasi digital keagamaan. Sedangkan aspek psikomotorik ditempuh menggunakan kegaiatan ekstrakurikuler kesenian keagamaan seperti contoh rebana.

Ekstrakurikuler "Hisbul Wathan" (Sorong, Volume 3, Nomor 1. 2018. Hal 90

${ }_{22}$ Mahmudah Nur. Jurnal. Literasi Digital Keagamaan Aktivis Organisasi Keagamaan di Madrasah Aliyah Negeri (MAN) di Kota Bandung. (Bandung, Jurnal Smart Studi Masyarakat, Religi dan Tradisi. Volume 05 No. 01.2019)Hal 01

${ }^{23}$ Suciati Nur Apriyanti, Syarip Hidayat, Jurnal. Pendidikan Karakter; Penumbuhan Kreativitas siswa melalui Program Ekstrakurikuler Teater di Sekolah Dasar. Vol. 6, No. 1 (2019). Hal. 235

${ }^{24}$ Irawati A. Sahman, dkk, Jurnal. Peranan Ekstrakurikuler Seni Kaligrafi dalam Meningkatkan Kreatifitas Peserta didik di Madrasah Aliyah Muhammadiyah Nunu Palu.Fakultas 


\section{Kesimpulan}

Kurikulum 2013 menjadi kurikulum aktif di era pendidikan sekarang. Tentunya banyak perubahan dari kurikulum sebelumnya. Setidaknya terdapat tiga komponen penting yang harus dicapai yaitu Penguatan Pendidikan karakter, Penguatan Budaya Literasi, dan Pembelajaran Abad 21. Untuk pemenuhan beberapa tujuan tersebut bisa di capai salah satunya dengan desain kurikulum ko kurikuler dan ekstra kurikuler.

Kegiatan Kokurikuler adalah kegiatan yang sangat erat sekali dan menunjang serta membantu kegiatan intrakurikuler biasanya dilaksanakan diluar jadwal intrakurikuler dengan maksud agar siswa lebih memahami dan memperdalam materi yang ada di intrakurikuler. Kegiatan ekstrakurikuler adalah pengembangan kepribadian peserta didik. Oleh karena itu kepribadian dewasa dapat menjadi tujuan utama dalam kegiatan ekstrakurikuler. Untuk menjalankan kegiatan ekstrakurikuler dibutuhkan proses atau tahapan belajar agar kegiatan dapat berjalan dengan baik.

Adapun tujuan dari kegiatan kokurikuler dan ekstrakurikuler adalah untuk memperdalam dan memperluas wawasan siswa. Kegiatan kokurikuler dan ekstrakurikuler juga berfungsi untuk pengembangan, sosial, rekreatif, dan persiapan karir. Kegiatan kokurikuler dan ekstrakurikuler juga memiliki prinsip seperti individual, keterlibatan aktif, pilihan, menyenangkan, etos kerja dan kemanfaatan sosial. Disamping itu kegiatan kokurikuler dan ekstrakurikuler juga memiliki dampak positif dan negatif.

Ko kurikuler dan ekstrakurikuler sangat bermanfaat untuk mencapai tujuan-tujuan yang ada dalam kurikulum 2013 asal dengan beban yang diperhitungkan dan tidak membebani siswa. Dilaksanakan dengan cara yang tidak membosankan sehingga bisa berjalan sebagai mana mestinya. Kegiatan Ko kurikuler dan ekstrakurikuler berperan untuk mencapai tujuan dari agenda di dalam kurikulum 2013. Masing-masing mempunyai jenis kegiatan tersendiri yang 
mampu bermanfaat untuk mencapai kurikulum 2013. Ko kurikuler dan Ekstrakurikuler dalam hal ini berperan sangat penting untuk mencapai aspek afektif dan psikomotorik dan tidak didapatkan saat pembelajaran di kelas mengingat waktu yang sangat singkat. Serta sangat membantu dalam mengembangkan nilai-nilai religious dari dalam diri siswa. Selain itu, bukan hanya siswa saja yang dibebani tanggung jawab, namun seluruh pihak sekolah terlatih untuk menyelesaikan tugas dengan baik dalam pelaksaaan kegiatan Ko kurikuler dan ekstrakurikuler. Ketiga aspek tersebut selanjutnya berperan penting dalam pencapaian agenda kurikulum 2013 yang terdiri dari tiga agenda besar yaitu penguatan budya literasi, penguatan pendidikan karakter dan pembelajaran abad 21. 


\section{DAFTAR PUSTAKA}

Abdul Malik Kusuma Negara, Skripsi. 2017. Pembinaan Karakter Keislaman Siswa Melalui Ko-Kurikuler PAI di MA Muhammadiyah Baturetno, Wonogiri. Pendidikan Agama Islam Fakultas Ilmu Tarbiyah dan Keguruan Universitas Islam Negeri Sunan Kalijaga Yogyakarta

Abdullah Idi. 1999. Pengembangan Kurikulum: Teori dan Praktik. Jakarta: Gaya Media Pratama,

Aisyah Rahmawati, Skripsi. 2019. Penguatan Karakter Gemar Membaca dan Rasa Ingin Tahu Siswa Melalui Gerakan Literasi Sekolah di SD Muhammadiyah Program Khusus Kottabarat Surakarta Tahun Ajaran 2018/2019. Pendidikan Guru Sekolah Dasar Fakultas Ilmu Keguruan Dan Pendidikan Universitas Muhammadiyah Surakarta

Asri Harfiyani,. Jurnal. 2018. Penguatan Pendidikan Karakter Melalui Budaya Literasi Dalam Konteks Pembelajaran Abad 21 di Sekolah Dasar. Prosiding Seminar dan Diskusi Nasional Pendidikan Dasar Program Pascasarjana, Universitas Negeri Jakarta.

Budi Santoso, Jurnal. 2018. Penguatan Pendidikan Karakter melalui Kegiatan Ekstrakurikuler "Hisbul Wathan" (Sorong, Volume 3, Nomor 1

Departemen Pendidikan dan Kebudayaan Direktorat Jendral Pendidikan Dasar dan Menengah Direktorat Pendidikan Menengah Umum 1984 Petunjuk Pelaksanaan dan Pengelolaan Kurikulum 1984 Sekolah Menengah Umum Tingkat Atas (SMA) Jakarta

Ferlina Khoirun Nisa, Skripsi. 2018. Evaluasi Program Ko-Kurikuler Sinematografi"Two Weeks One Video" pada Siswa Kelas X Prodi Multimedia di SMK Negeri 11 Semarang", ( Semarang: Kurikulum Teknologi Pendidikan Fakultas Ilmu Pendidikan Universitas Negeri Semarang

Greenstein, L. 2012. Assessing 21st Century Skills: a guide to evaluating mastery and authentic learning.London: Sage Publications Ltd.

Hermanto SP, Jurnal. Penambahan Program Wajib Kokurikuler Sebagai Redesain Sistem Pendidikan Guru. PLB FIP UNY.

Idris Apandi. Tiga Agenda Penting Implementasi Kurikulum 2013. Di akses dari

https://www.kompasiana.com/idrisapandi/58c84e225597733c447dcc57/tig 
a-agenda-penting-implementasi- kurikulum-2013?page=all. Pada Tanggal 28 Maret 2020 Pukul 11.5

Irawati A. Sahman, dkk, Jurnal. Peranan Ekstrakurikuler Seni Kaligrafi dalam Meningkatkan Kreatifitas Peserta didik di Madrasah Aliyah Muhammadiyah Nunu Palu.Fakultas Agama Islam Universitas Muhammadiyah Palu. Hal.994

Lazuardi Haura, Global Islamic School, Intrakurikuler SD, di akses melalui https://www.lazuardi- haura.sch.id pada 16 mei 2020 pukul 19.51

Mahmudah Nur. Jurnal. 2019. Literasi Digital Keagamaan Aktivis Organisasi Keagamaan di Madrasah Aliyah Negeri (MAN) di Kota Bandung. (Bandung, Jurnal Smart Studi Masyarakat, Religi dan Tradisi. Volume 05 No. 01

Moh. Uzer Usman dan Lilis Setiawati, 1993. Upaya Optimalisasi Kegiatan Belajar Mengajar, (Bandung: Remaja Rosdakarya

Muh. Hambali, Eva Yulianti. Jurnal, 2018. Ekstrakurikuler Keagamaan terhadap Pembentukan Karakter Religius Peserta Didik di Kota Majapahit.Malang, UIN Maulana Malik Ibrahim Malang, vol 05. No.02,

Muh. Hambali, Eva Yulianti. Jurnal. 2018. Ekstrakurikuler Keagamaan terhadap Pembentukan Karakter Religius Peserta Didik di Kota Majapahit.(Malang, UIN Maulana Malik Ibrahim Malang, vol 05. No.02

Nurul Husni Hidayah, Skripsi. 2018. Peran Program Ko-Kurikuler untuk Memotivasi Siswa Menutup Aurat (Berhijab) dalam Keseharian (Studi Kasus di MTs. Gunung Jati Jombang).Jurusan Pendidikan Agama Islam GFakultas Ilmu Trabiyah dan Keguruan UIN Maulana Malik Ibrahim Malang

Peraturan Menteri Pendidikan Dan Kebudayaan Republik Indonesia Nomor 81A Tahun 2013 Tentang Implementasi Kurikulum

Permendikbud no.18 A 2013

Romadon Taufik, Jurnal. 2015. Manajemen Kegiatan Ekstrakurikuler Berbasis Karakter Siswa. Manajer Pendidikan, Volume 9, Nomor 4

S. Nasution. 1982. Asas-Asas Kurikulum. Bandung: Jemmars, 1982

Suciati Nur Apriyanti, Syarip Hidayat, Jurnal. 2019. Pendidikan Karakter; Penumbuhan Kreativitas siswa melalui Program Ekstrakurikuler Teater di Sekolah Dasar. Vol. 6, No. 1 
